\title{
Effective Business Strategy: Key to Winning Business Competition in Industrial Estate
}

\author{
Sri Sarjana \\ Strategic Management \\ SMKN 1 Cikarang Barat \\ Bekasi, Indonesia \\ srisarjana@gmail.com
}

\author{
Nur Khayati \\ Sociology \& Anthropology \\ SMAN 1 Cikarang Utara \\ Bekasi, Indonesia \\ nurkayati.pch@gmail.com
}

\begin{abstract}
Global competition requires high speed, accuracy, creativity and consistency to win business through strengthening optimal competitiveness. Choosing the right business strategy create effective business achievements to be able to compete in the face of uncertain and turbulence economic conditions. This study empirically investigates important role of human capital, infrastructure, supply chain, and technology on company's business strategy in industrial estate and its impact on strengthening competitiveness of manufacturing industry. Authors conducted survey of companies in industrial estate to test hypotheses and apply survey analysis techniques using structural equation modeling. Results of this study concluded that human capital, infrastructure, supply chain, and technology have positive influence on business strategies and have positive impact on competitiveness of manufacturing industries, especially those located in industrial estates. In addition, importance of choosing right business strategy greatly determines how much this business has superior competitiveness compared to its business competitors. This research is expected to be used as suggestion and reference for business units and manufacturing industries to be used as one of considerations in the development of companies in industrial estates that are being developed widely, especially outside Java by government to get best competitiveness.
\end{abstract}

Keywords-business strategy, competitiveness, supply chain, human capital, industrial estate

\section{INTRODUCTION}

Rapid development of world economy and uncertain business conditions now results in increasingly complex and dynamic problems faced by business sector [1]. Almost all developing countries face two main problems, first how to achieve economic growth, and secondly how to maintain economic growth [2]. For every business unit, the competitive strategy is required to win competition in uncertain and turbulent business environment especially in manufacturing industry [3]. Environmental turbulence in business combined measure of changeability and predictability of the firm's environment, rapidity of change refers to ratio of speed with challenges evolve in environment and speed of the firm's response [4]. One explanation of low level of Indonesia's economic competitiveness at international level is weak law enforcement, especially because eradicating corruption and bureaucratic reform have not been optimal [5]. Companies in industrial estate need to be considered to solve the problems in business decline [6]. The essence of competition lies in how companies are able to create products or services that are cheaper, better quality, and reach consumer faster than business competitors.
Main objective in development of this research is to increase competitiveness for manufacturing industries located in industrial estates through selection of business strategies that are appropriate, effective and efficient in growing the business. Selection of right business strategy is supported by contribution of good human capital, adequate infrastructure, interconnected supply chains, and innovation technology that refers to the present so that the manufacturing industry in industrial estate can grow and develop optimally and even win business competition that is increasingly uncertain. This research is limited to problems that only refer to human capital, infrastructure, supply chain, and technology innovation, business strategy and competitiveness.

\section{LITERATURE REVIEW}

\section{A. Competitiveness (COM)}

Competitiveness create added value and increase wealth by managing assets and processes, attractiveness, aggressiveness and closeness by integrating these relationships [7]. Competitiveness is the company's ability to compete with other companies to create value, enhanced by application of appropriate competitive strategies [8], effort to increase bargaining position in order to maximize achievement of our goals in dealing with position and purpose of other parties [9]. Regional competitiveness is defined as the ability of region to achieve economic growth to create a high level of prosperity and sustainability [10].

\section{B. Business Strategy (BS)}

BS are decision to focus on competing positions in industry and certain market segments [11]. BS developed by emphasizing improvement in the position of competition for company products or services [12]. Development of BS dimensions consists of low cost strategies, differentiation, speed-based strategies, and market focus [13], cost leadership, differentiation, focus on cost, focus on differentiation, and integrated differentiation [14].

Cost leadership is low-cost BS that is demonstrated for industrial estates that requires aggressively building the entire facility efficiently, reducing prices significantly, controlling costs and costs tightly. To get optimal cost leadership, there are number of things that need to be avoided including research and development, services, salespeople, and advertisements. Other cost leadership strategies must be developed in industrial estate can be done through efficiency of operational costs and determining competitive prices. Differentiation strategy is directed to broad industrial area by involving the creation of a product or service so that company must set premium price. Through differentiation 
strategy, company seeks to have differences in several dimensions product or service so that it has added value to consumers. Differentiation developed by companies can have more than one success in one industry, this depends on the number of attributes that are considered important and needed by buyers. Product superiority and variety of products produced by companies are important differentiation strategies to be implemented to obtain efficient business strategies. Focus strategy is BS that has focus on group of buyers or specific geographical location in this case located in industrial estate so that company's activities focus on serving this niche market, and ignore other markets. Companies that use this focus strategy will look for cost advantages that are seen based on market segments including proximity and ease of access in a particular area. Speed strategy needed by companies includes speed of the company's response to customer needs, speed of the company in anticipating competitor movements, and speed of company in utilizing information technology developments for improvement.

\section{Human Capital (HC)}

$\mathrm{HC}$ is an intangible asset that is not easy to measure considering that humans have dynamic properties and relatively change with changes in situations and conditions [15]. HC is combination of knowledge, skills, innovation and ability of a person to carry out their duties so that they can create value to achieve goals [16]. HC reflects the company's collective ability to produce the best solutions based on knowledge if company is able to use the knowledge it has. The dimensions of $\mathrm{HC}$ included individual capability, individual motivation, leadership, organizational climate, and work group effectiveness [17]

\section{Infrastructure (IN)}

Public infrastructure including roads, extension services, electricity, electricity, water sources, irrigation, education centers, and health centers is very important for the economy and society [18]. Reliable infrastructure is the backbone of the economy, providing access to markets, jobs and social services [19]. It is important to make various efforts to improve transportation planning systematically [20]. Flexible strategies in infrastructure is proactively designed to be changed in the future have potential to meet water supply needs without expensive overbuilding [21].

\section{E. Supply Chain $(S C)$}

SC refers to overall management of production, distribution and marketing processes in which consumers are exposed [22]. SC management is an integrated system that coordinates the entire process at company in preparing and delivering products to consumers [23]. Dimensions in development of SC include interdependence between functions, internal function integration, integration of planning and supervision, external integration with business partners [24]. Manufacturing industry must realize that to produce optimal SC management not only requires and provides products that are cheap, high quality, fast response, but also requires the participation of all parties starting from suppliers who process raw materials from nature to components, factories that converting components and raw materials into finished products, transportation companies that send raw materials from suppliers to factories, and distribution networks that will deliver products to customers.

\section{F. Technology innovation (TE)}

TE is source of creation for new technologies to improve human well-being, and as a prerequisite for the dissemination of knowledge [25]. Dimensions of technology adaptation include mobility, internet of things, cloud computing and big data analytics [26]. Innovation policy has solid value when aimed at a particular technology that is deemed to contribute to social welfare but that requires government intervention to grow [27]. TE increases complexity, costs, and risks as reciprocal of changes in business processes, high competitive pressures, drastic and rapid changes in technology itself [28].

\section{RESEARCH METHOD}

This study uses verification approach that tests the hypotheses under study. Verification analysis was carried out to determine the effect between variables tested using structural equation modeling (SEM) with variables used including HC, IN, SC, TE, BS, and COM. Unit of analysis is manufacturing industry located in West Java, while observation unit is managers level in manufacturing industry located in industrial estate. This research conducted using survey method with total sample of 220 manufacturing industries. Data collection techniques are obtained by collecting data directly to data sources through questionnaires and interviews. Analysis technique used descriptive analysis. Hypothesis test is to use SEM with Lisrel program to examine series of relationships between latent variables with limited population numbers.

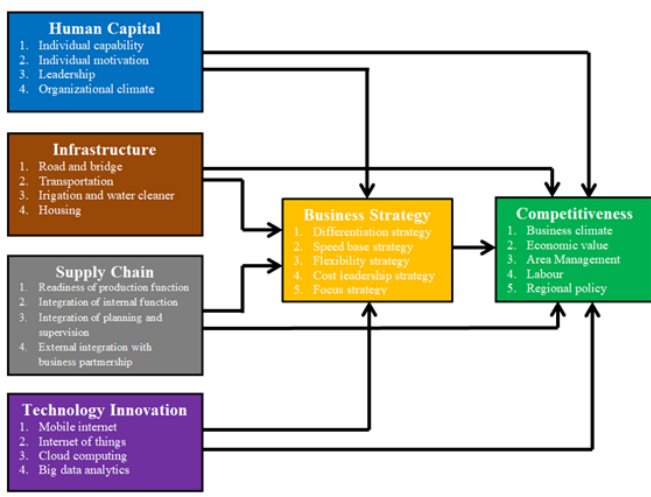

Fig. 1. Research paradigm

Hypotheses that can be proposed in this study are:

$\mathrm{H}_{1}=\mathrm{HC}$, IN, SC, TE have significant effect on BS.

$\mathrm{H}_{2}=\mathrm{HC}$, IN, SC, TE have significant effect on COM.

$\mathrm{H}_{3}=$ BS has significant effect on COM.

\section{RESULT AND DISCUSSION}

Analysis of this study used multivariate statistics by developing structural equation modeling tests. High complexity of the model developed and supplemented by the number of variables tested with construct formed by various indicators. SEM analysis using Lisrel 8.8 program is the most appropriate choice in completing calculations in this case. Evaluation of model needs to be tested first, it is necessary to find out whether the structural model formed is feasible for further analysis. Questionnaire data collected from 
respondents totaling 220 with complete data in filling out questionnaire had fulfilled the requirements properly which were used in the study so that the procedure as whole then data was ready to be processed statistically.

TABLE I. RESPONDENT CHARACTERISTIC

\begin{tabular}{|c|c|c|c|}
\hline \multirow{2}{*}{ Profile } & \multicolumn{3}{|c|}{ Respondent } \\
\hline & Criteria & Number & $\%$ \\
\hline \multirow[t]{3}{*}{ Gender } & Male & 174 & 79.1 \\
\hline & Female & 46 & 20.9 \\
\hline & $<30$ years & 17 & 7.7 \\
\hline \multirow[t]{4}{*}{ Age } & $30-40$ years & 54 & 24.5 \\
\hline & $40-50$ years & 123 & 55.9 \\
\hline & $>50$ years & 26 & 11.8 \\
\hline & High school & 39 & 17.7 \\
\hline \multirow{3}{*}{ Education } & Diploma & 45 & 20.5 \\
\hline & Bachelor Degree & 118 & 53.6 \\
\hline & Master Degree & 18 & 8.2 \\
\hline \multirow{6}{*}{$\begin{array}{l}\text { Industrial } \\
\text { background }\end{array}$} & Automotive & 71 & 32.3 \\
\hline & Electronic & 48 & 21.8 \\
\hline & Food \& beverages & 19 & 8.6 \\
\hline & Consumers good & 29 & 13.2 \\
\hline & Logistic & 17 & 7.7 \\
\hline & Services & 36 & 16.4 \\
\hline
\end{tabular}

Characteristics of respondents in this study can be shown referring to profiles in table 1 . Four criteria in the profile of respondents consisted of gender, age, education and industrial background. Based on gender of respondents, it is known that number of male respondents is 174 and number of female respondents is 46 . From this data it is known that respondents with male $79.1 \%$ have a greater number than female respondents $20.9 \%$ because in general the main task of earning a living is men.

In the age data, it can be shown that respondents with age less than 30 years have number of respondents 17, 30 - 40 years have number of respondents 54, 40-50 years have number of respondents 123 , more than 50 years have number of respondents 26. At age 40- 50 years, the number of respondents involved in this study amounted to $55.9 \%$ and was the most compared to other age categories because this age was the level of employee maturity and high level of productivity in work activities. The number of respondents with high school education has 39 respondents, diplomas have 45 respondents, bachelor degrees have 118 respondents, and master degree has number of respondents 18 . Number of respondents with bachelor degree criteria has the highest number of $53.6 \%$ because respondent who chosen in this study was at the level of management of company in manufacturing industry so that average level of education was quite good. Whereas in the background of manufacturing industry where respondents work, automotive industry have 71 respondents, electronics have 48 respondents, food \& beverages have 19 respondents, consumers have 29 respondents, logistics have 17 respondents, and service industry have number of respondents is 36 . This shows that automotive industry have largest number of respondents $32.3 \%$ because the population of manufacturing industry with business lines in automotive is also most compared to other industries.

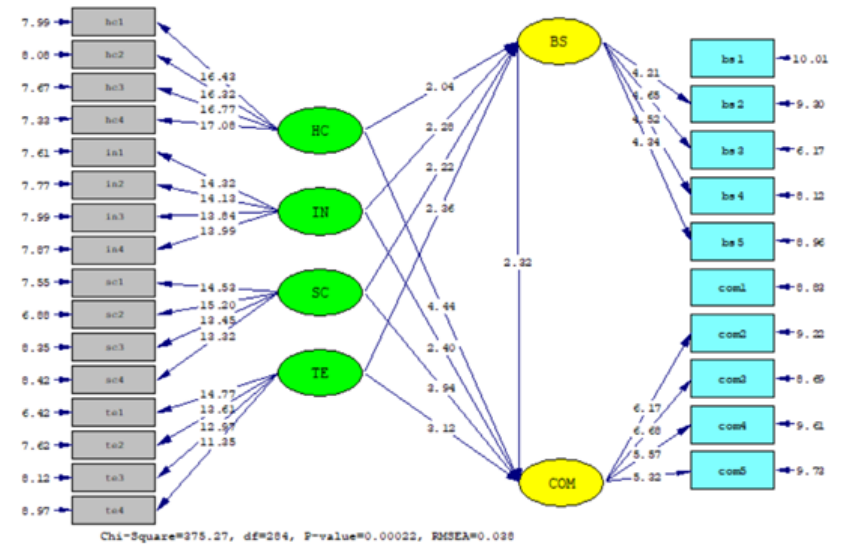

Fig. 2. Structural model estimation

The measurement results of structural model show the influence of $\mathrm{HC}, \mathrm{IN}, \mathrm{SC}$, and TE on BS and implications for $\mathrm{COM}$ in strengthening business sector in manufacturing industry as standardized solution as indicator to measure direct influence between variables tested and shows the significance value measured, shown in the figure 2. Effect value of $\mathrm{HC}$ on BS is $\Upsilon_{11}=0.17$, effect value of IN on BS is $\Upsilon_{21}=0.21$, effect value of SC on BS is $\Upsilon_{31}=0.19$, effect value of TE on $\mathrm{BS}$ is $\Upsilon_{41}=0.21$, effect value of $\mathrm{HC}$ on COM is $\Upsilon_{12}=0.34$, effect value of IN on COM is $\Upsilon_{22}=$ 0.18 , effect value of SC on COM is $\Upsilon_{32}=0.31$, effect value of TE on COM is $\Upsilon_{42}=0.24$, effect value of BS on COM is $\beta_{21}=0.23$. Based on the exposure of standardized solution values shown, it can be seen that overall effect values between variables tested have significant direct effect.

The results of simultaneous hypothesis testing produced $\mathrm{H}_{1}$ which states that $\mathrm{HC}$, IN, SC, and TE have direct effect on BS. Some indicators have large contribution from results of hypothesis testing on four independent variables so that it affects intervening variable. The results of analysis revealed that organizational climate as indicator has major contribution in $\mathrm{HC}$ so that it has direct effect on BS in development of manufacturing industries at industrial estate. Transportation, roads and bridges support IN optimally so that it have direct effect on BS. Contribution from integration of planning and supervision of SC has integration on BS. Mobile internet contributes greatly to development of TE so that it has direct effect on BS. Organizational climate, transportation, roads and bridges, integration of planning and supervision, and mobile internet play an important role in strengthening BS, especially for manufacturing industries in industrial estate.

Simultaneous analysis in $\mathrm{H}_{2}$ states that $\mathrm{HC}, \mathrm{IN}, \mathrm{SC}$, and TE have direct effect on COM. Two indicators that contribute greatly to $\mathrm{HC}$ so that it has direct effect on COM include climate organizational and leadership. In addition, transportation, roads and bridges as important parts of IN have direct effect on COM. Indicators needed by SC are not only integration of planning and supervision, but external integration with business partners so that it has direct effect 
on COM. Mobile internet and internet of things have important contributions in development of TE so that it has direct effect on COM. Leadership, organizational climate, transportation, roads and bridges, integration of planning and supervision, external integration with business partners, mobile internet and internet of things are some of the indicators needed by manufacturing industry to leverage $\mathrm{COM}$ in industrial estate. For the last hypothesis test, $\mathrm{H}_{3}$ test concluded that BS has direct effect on COM. Flexibility strategy and cost leadership strategy are two indicators that contribute greatly to strengthening BS so that it has direct effect on increasing the COM of manufacturing industry.

TABLE II. GOODNESS OF FIT INDEX

\begin{tabular}{|c|c|c|c|}
\hline \multirow{2}{*}{ Index } & \multicolumn{3}{|c|}{ Goodness of Fit Index } \\
\cline { 2 - 4 } & Criteria & Result & Remark \\
\hline \multirow{2}{*}{ GFI } & $\geq 0.90$ & 0.88 & Marginal Fit \\
NFI & $\geq 0.90$ & 0.92 & Good Fit \\
NNFI & $\geq 0.90$ & 0.97 & Good Fit \\
CFI & $\geq 0.90$ & 0.98 & Good Fit \\
IFI & $\geq 0.90$ & 0.98 & Good Fit \\
RFI & $\geq 0.90$ & 0.91 & Good Fit \\
PNFI & $0-1$ & 0.80 & Marginal Fit \\
AGFI & $0-1$ & 0.86 & Marginal Fit \\
& & & \\
\hline
\end{tabular}

SEM is one of multivariate analyzes that can analyze influence between variables more complexly, besides being able to combine measurements or confirmatory factor analysis and structural models into simultaneous statistical tests. Some results of compatibility test on multivariate analysis using SEM in the form of overall model fit, measurement model fit, and structural model fit, where the three criteria can be represented by measurements of GFI, NFI, NNFI, CFI, IFI, RFI, PNFI, AGFI. The results of measurement goodness of fit with several match index criteria that include eight criteria presented in the table. If index value is obtained $\geq 0.9$, index is categorized as fit, or if index is close to 1 then AGFI and PNFI criteria are categorized as fit. The measurement index can be categorized as marginal if the value obtained is $0.8 \leq \mathrm{GOF} \leq$ 0.9 . The model fit test in this study describes eight results criteria obtained with five criteria stated good fit consists of NFI, NNFI, CFI, IFI, RFI and three other criteria stated marginal fit, namely GFI, PNFI, and AGFI.

TABLE III. RESULT OF RESEARCH HYPOTHESES

\begin{tabular}{|c|c|c|c|}
\hline \multirow{2}{*}{ Hypotheses } & \multicolumn{3}{|c|}{ Research Hypotheses } \\
\cline { 2 - 4 } & $\boldsymbol{t}$-value & $\begin{array}{c}\text { Standardized } \\
\text { Solution }\end{array}$ & Conclusion \\
\hline $\mathrm{H}_{1}$ & 2.04 & 0.17 & Accepted \\
$\mathrm{HC} \rightarrow \mathrm{BS}$ & 2.28 & 0.21 & Accepted \\
$\mathrm{IN} \rightarrow \mathrm{BS}$ & 2.22 & 0.19 & Accepted \\
$\mathrm{SC} \rightarrow \mathrm{BS}$ & 2.36 & 0.21 & Accepted \\
$\mathrm{TE} \rightarrow \mathrm{BS}$ & &
\end{tabular}

\begin{tabular}{|c|c|c|c|}
\hline \multirow{2}{*}{ Hypotheses } & \multicolumn{3}{|c|}{ Research Hypotheses } \\
\cline { 2 - 4 } & $\boldsymbol{t}$-value & $\begin{array}{c}\text { Standardized } \\
\text { Solution }\end{array}$ & Conclusion \\
\hline $\mathrm{H}_{2}$ & & & \\
$\mathrm{HC} \rightarrow \mathrm{COM}$ & 4.44 & 0.34 & Accepted \\
$\mathrm{IN} \rightarrow \mathrm{COM}$ & 2.40 & 0.18 & Accepted \\
$\mathrm{SC} \rightarrow \mathrm{COM}$ & 3.94 & 0.31 & Accepted \\
$\mathrm{TE} \rightarrow \mathrm{COM}$ & 3.12 & 0.24 & Accepted \\
$\mathrm{H}_{3}$ & & & Accepted \\
$\mathrm{BS} \rightarrow \mathrm{COM}$ & 2.32 & 0.23 & \\
\hline
\end{tabular}

In this study there are three hypotheses by utilizing six tested variables such as $\mathrm{HC}$, IN, SC, TE, BS, and COM with results that can be stated that three hypotheses are significant and hypothesis can be accepted based on the table 3 . The entire hypothesis tested has $\mathrm{t}_{\text {-value }}>1.96$ so that it is declared significant. The greatest significance value is determined by direct influence of $\mathrm{HC}$ on $\mathrm{COM}$ with value of $\mathrm{t}$-value $=4.44$ even without BS as intervening variables. Organizational climate and leadership by company management in manufacturing industry have major contribution in strengthening HC. This can be interpreted that organizational climate and leadership are able to foster increased business performance so as to create superior manufacturing industry competitiveness. In addition, the other significance value is direct influence of $\mathrm{SC}$ on $\mathrm{COM}$ with $\mathrm{t}_{\text {-value }}$ of 3.94. The biggest contribution $\mathrm{SC}$ in developing the $\mathrm{COM}$ of manufacturing industry lies in integration of internal functions and readiness of production functions.

$\mathrm{H}_{1}$ measurement results where the significance value of $\mathrm{t}$. value from the effect of $\mathrm{HC}$ on BS is 2.04, influence of IN on $\mathrm{BS}$ is 2.28 , influence of SC on BS is 2.22, influence of TE on $\mathrm{BS}$ is 2.36. For $\mathrm{H}_{2}$ measurement, the significance value of

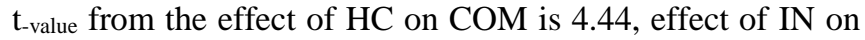
COM is 2.40, effect of SC on COM is 3.94, and effect of TE on COM is 3.12. As for the measurement of $\mathrm{H}_{3}$, the significance value of $t_{\text {-value }}$ come from the effect of $\mathrm{BS}$ on COM of 2.32 .

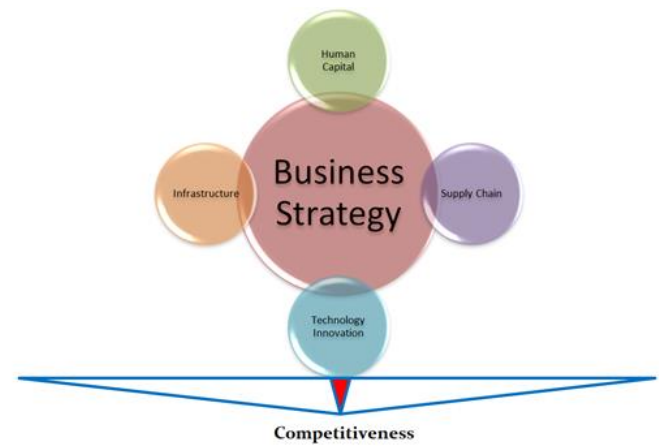

Fig. 3. Novelty of Industrial Estate Business Strategy Model

Based on research findings, novelty in this research is called industrial estate BS model. This model emphasizes the importance of considering flexibility strategies and cost leadership strategies in developing BS by companies with business lines in manufacturing industries especially in industrial estate. On the other hand, this model also emphasizes important role of regional and labor management 
as indicator in strengthening $\mathrm{COM}$ of manufacturing industries at industrial estates. This is based on idea that current situation is very difficult to develop effective BS in disruptive environment so that various resources are needed to achieve the best COM for development of manufacturing industry. In disruptive business environment, tendency of business sector in manufacturing industry to achieve optimal corporate performance by implementing efficient BS. BS in industrial estate can be realized through approach of $\mathrm{HC}$, IN, $\mathrm{SC}$, and TE that can be optimized effectively and efficiently. A superior BS is able to encourage the creation of superior $\mathrm{COM}$ in industrial estate, especially in the manufacturing industry business sector by involving various stakeholders. $\mathrm{BS}$ in industrial estate is directed at building competitiveness so that manufacturing industry gets clear direction about business vision and mission that will be applied in the future.

\section{CONCLUSIONS}

Results of study based on analysis developed in this research carried out in manufacturing industry which examined the influence of human capital, infrastructure, supply chain and technology innovation on business strategy so that it impacted to competitiveness, it can be concluded that human capital, infrastructure, supply chain and technology innovation has significant effect on business strategy. Human capital, infrastructure, supply chain and technology innovation have significant effect on competitiveness, and business strategy has significant effect on competitiveness. Organizational climate and leadership have important role in the development of human capital in manufacturing industry. Human capital can drive company's competitiveness [16]. Infrastructure development in industrial estates requires major contributions such as transportation, roads and bridges to facilitate access to supporting facilities for economic system in this area.

In addition, to strengthen supply chain management to support various needs of manufacturing industry, commitment is needed to ensure the continuity for integration of internal functions and readiness of production functions so that this series of activities can be complementary and maintained to remain stable. Manufacturing industries must develop sustainable systems and create awareness among manufacturers to understand the importance of sustainability among supply chain players [29]. Mobile internet and internet of things play major role in creating technology innovation especially for development of products or services that produced in accordance with consumer needs and in order to meet global demands. To develop industrial estate through expansion and strengthening of manufacturing industries in various sectors, it is necessary to consider flexibility strategy and cost leadership strategy in supporting management's efforts to continue grow in implementing its business strategy. In order to obtain optimal company competitiveness, governance of manufacturing industry needs to be taken seriously, especially in area management and economic value so as to be able to compete with business competitors, and even be able to win business competition on a larger business scale.

Findings of this study can used as references by stakeholders, especially for regional governments and the ministry of industry, in relation to industrial estate development plans carried out not only in Java, but also outside Java with the aim of national industrial equality. Business strategy applied by manufacturing industry in developing industrial estates has not been fully influenced by human capital, infrastructure, supply chain and technology innovation so that in carrying out next research several variables must be added that have different focus and characteristics so that explanation of concepts and results of research is able to complete a variety of knowledge needed by manufacturing industry.

\section{REFERENCES}

[1] Subarjo and F. W. Sari, "Analisis Turnover Terhadap Kinerja Keuangan Dengan Revenue Sebagai Variabel Moderasi," J. Perilaku dan Strateg. Bisnis, vol. 5, no. 2, pp. 201-220, 2017.

[2] K. Munir and S. Arshad, "Factor accumulation and economic growth in Pakistan: incorporating human capital," Int. J. Soc. Econ., vol. 45, no. 3, pp. 480-491, 2018.

[3] S. Sarjana and N. Khayati, "Industrial Estate Development: Challenges And Opportunities In Strengthening Competitiveness Of Manufacturing Industries Industrial Estate Development: Challenges and Opportunities in Strengthening Competitiveness of Manufacturing Industries," Indones. J. Dev. Plan., vol. II, no. 2, pp. 152-169, 2018.

[4] S. Sarjana, "Dynamic capabilities in manufacturing: the main role of manufacturing capability, knowledge re-sources and environmental turbulence to improve enterprise performance," $J$. Entrep. Bus. Econ., vol. 3, no. 2, pp. 41-64, 2015.

[5] M. Risnain, "Peningkatan Daya Saing Bangsa Melalui Reformasi Pembangunan Hukum Dalam Mewujudkan Cita Negara Kesejahteraan," J. Rechts Vinding Media Pembin. Huk. Nas., vol. 5, no. 3, pp. 291-304, 2016.

[6] S. Sarjana, D. Kartini, P. Rufaidah, and Yunizar, "Reputation Development Strategy for Corporate Operating in Industrial Estate," Acad. Strateg. Manag. J., vol. 17, no. 2, pp. 1-12, 2018.

[7] T. Armenski, D. O. Gomezelj, B. Djurdjev, L. Deri, and D. Aleksandra, "Destination Competitiveness: A Challenging Process for Serbia, Human Geographies.," J. Stud. Res. Hum. Geogr., vol. 5, no. 1, pp. 19-33, 2011.

[8] S. K. Anggraeni, M. S. Maarif, Sukardi, and S. Raharja, "Strategi Peningkatan Daya Saing Usaha Kecil Menengah Berbasis Olahan Ikan Di Indonesia: Suatu Tinjauan," J. Ind. Serv., vol. 3, no. 1, pp. 331-341, 2017.

[9] R. Imawan, "Peningkatan Daya Saing: Pendekatan ParadigmatikPolitis," J. Ilmu Sos. Ilmu Polit., vol. 6, no. 1, pp. 79-104, 2002.

[10] Adijanto, Kajian Atas Kebijakan Penguatan Daya Saing Daerah Dalam Rangka Peningkatan Kesejahteraan Masyarakat. Jakarta: Dirjen Perimbangan Keuangan - Kemenkeu RI, 2017.

[11] T. L. Wheelen and D. J. Hunger, Strategic Management and Business Policy: Toward Global Sustainability, Thirteenth Edition. New Jersey: Pearson Education, Inc, 2012.

[12] S. M. Kahreh, H. Ahmadi, and A. Hashemi, "Achieving Competitive Advantage Through Empowering Employees: An Empirical Study," Far East J. Psychol. Bus., vol. 3, no. 2, pp. 2637, 2011.

[13] J. A. Pearce and R. B. Robinson, Strategic Management: Planning for Domestic and Global Competition. New Jersey: McGraw Hill, 2015.

[14] M. A. Hitt, R. D. Ireland, and R. E. Hoskisson, Strategic Management: Competitiveness and Globalization, Concepts and Cases. Stamford: Cengage Learning, 2015.

[15] C. Hidayat, "Analisis Model Pengukuran Human Capital Dalam Organisasi," Binus Bus. Rev., vol. 4, no. 2, pp. 879-885, 2013.

[16] M. D. P. Ongkorahardjo, A. Susanto, and D. Rachmawati, "Analisis Pengaruh Human Capital Terhadap Kinerja Perusahaan ( Studi Empiris pada Kantor Akuntan Publik di Indonesia )," $J$. Akunt. DAN Keuang., vol. 10, no. 1, pp. 11-21, 2008.

[17] A. Mayo, "The Role of Employee Development in The Growth of Intellectual Capital," PersonalReview, vol. 29, no. 4, 2000.

[18] H. Nagesso, T. Ayele, and B. Nigussie, "Accessibility Of Rural Public Infrastructures And Food Security Among Rural 
Households In Kersa District, South Western Ethiopia," Res. Sci. Today J., vol. 1, no. 17, pp. 45-60, 2019.

[19] N. Limao and A. J. Venables, "Infrastructure, geographical disadvantage, transport costs, and trade," World Bank Econ. Rev., vol. 15, pp. 451-479, 2001.

[20] E. E. Koks, J. Rozenberg, C. Zorn, M. Tariverdi, M. Vousdoukas, S. A. Fraser, J. W. Hall, and S. Hallegatte, "A global multi-hazard risk analysis of road and railway infrastructure assets," Nat. Commun., vol. 10, no. 2677, pp. 1-11, 2019.

[21] S. Fletcher, M. Lickley, and K. Strzepek, "Learning about climate change uncertainty enables flexible water infrastructure planning," Nat. Commun., vol. 10, no. 1782, pp. 1-12, 2019.

[22] M. N. Marimin, Teknik dan Analisis Pengambilan Keputusan Fuzzy Dalam Manajemen Rantai Pasok. Bogor: IPB Press, 2013.

[23] R. Martono, Manajemen Logistik Terintegrasi. Jakarta: PPM Manajemen, 2015.

[24] M. Christhoper, Logistics and Supply Chain Management, Strategy for Reducing Cost and Improving Service. London: Prentice Hall Inc, 1998

[25] J. Feng and J. Yuan, "Effect of technology innovation and spillovers on the carbon intensity of human well - being," Springerplus, vol. 5, no. 346, pp. 1-8, 2016.

[26] R. Kasali, The Great Shifting. Jakarta: PT Gramedia, 2018

[27] A. Suwa and J. Jupesta, "Policy innovation for technology diffusion: a case-study of Japanese renewable energy public support programs," Sustain. Sci., vol. 7, pp. 185-197, 2012.

[28] O. Muthaher and M. Assegaf, "Model Pengembangan Inovasi Teknologi Dan Kelembagaan Kemitraan Rantaipasok Guna Meningkatkan Daya Saing UKM," J. Ekon. Bisnis, vol. 15, no. 1, pp. 62-73, 2014.

[29] B. Sarkar, M. Omair, and S. Choi, "A Multi-Objective Optimization of Energy, Economic, and Carbon Emission in a Production Model under Sustainable Supply Chain Management," Appl. Sci., vol. 8, no. 1744, pp. 1-25, 2018. 